\title{
Effect the liquid extract of Calendula officinalis in surgical wound healing process in the abdomen of mice.
}

\author{
Humberto M. Silva (IC), Joaquim M. B. Silva (PQ).
}

\begin{abstract}
Twenty-eight male Wistar rats were divided in two groups: Control Group (CG) - underwent incision and suture; and Incision and + COE Group (COEG) - underwent incision, suture and intraperitoneal administration of Calendula officinalis extract $(150 \mathrm{mg} / \mathrm{kg})$. On the third and seventh days after surgery, samples of incisional wounds were collected for immunohistochemical and tensile tests. The effectiveness of using liquid extract of Calendula officinalis has been shown to increase the limits of resistance and break in incisional wounds. Immunohistochemical tests are being performed.
\end{abstract}

Key words: Incisional hernias (IH), metalloproteinases, Calendula officinalis

\section{Introduction}

The occurrence of incisional hernias $(\mathrm{IH})$ ranges from ten to fifteen percent of patients undergoing laparotomy, what is attributed to higher expression of matrix metalloproteinases (MMPs) 1,2 and 13, whose substrates are collagen protein components of the extracellular matrix of tissues. Another factor associated with $\mathrm{IH}$ in laparotomy is the decrease of ratio of collagen type I and type III, which was associated with a marked expression of MMP-2 [1, 2].

Therefore, studies indicate that reducing the expression of MMPs, occurrences of $\mathrm{IHs}$ are minimized, and this can be done using drugs [2].

Thus, the objective of this project was to evaluate the effectiveness of the liquid extract of Calendula officinalis in the healing of surgical wounds [3].

\section{Results and Discussion}

Ethical approval for this research was obtained from the Research Ethics Committee of Campinas State University - UNICAMP. Twenty-eight male Wistar rats were distributed into two groups: Control Group (CG) - underwent incision and suture; Incision and + COE Group (COEG) underwent incision, suture, and intraperitoneal administration of the liquid extract of Calendula officinalis $(150 \mathrm{mg} / \mathrm{kg})$. On the third and seventh days after surgery, samples of incisional wounds were collected for immunohistochemical tensile tests.

Results of tensile tests are shown in Table 1, and Tukey test $(p<0.05)$ was used to compare the means.
Tabel 1. Results to tensile test - (1) resistance limit, $\mathrm{N}$; (2) displacement at resistance limit ( $\mathrm{mm})$; (3) stiffness, $\left(\mathrm{kN} \mathrm{m}^{-1}\right)$; and break limit $(\mathrm{N})$

\begin{tabular}{lcccc}
\hline Group & $(1)$ & $(2)$ & $(3)$ & $(4)$ \\
\hline $\begin{array}{l}\text { CG }(n=6) \\
\text { (3rd. day) }\end{array}$ & $4.18 \mathrm{a}$ & $5.06 \mathrm{a}$ & $8.52 \mathrm{a}$ & $0,98 \mathrm{a}$ \\
$\begin{array}{l}\text { COEG }(n=6) \\
\text { (3rd. day) }\end{array}$ & $10.06 \mathrm{a}$ & $9.94 \mathrm{a}$ & $2.09 \mathrm{a}$ & $2,30 \mathrm{~b}$ \\
$\begin{array}{l}\text { CG }(n=6) \\
\text { (7th. day) }\end{array}$ & $12.21 \mathrm{~b}$ & $5.65 \mathrm{~b}$ & $5.57 \mathrm{~b}$ & $2,44 \mathrm{c}$ \\
$\begin{array}{l}\text { COEG }(n=7) \\
\text { (7th. day) }\end{array}$ & $17.52 \mathrm{c}$ & $5.97 \mathrm{~b}$ & $6.11 \mathrm{~b}$ & $3,51 \mathrm{~d}$ \\
\hline
\end{tabular}

Notes: Means labelled with the same letter are not significantly different from each other following the Tukey test $(p<0.05)$.

\section{Conclusions}

According to the experiments, the use of liquid extract of Calendula officinalis increased the limits of resistance and break in incisional wounds.

\section{Acknowledgement}

The authors are grateful to Botica Silvestre for supplying the Callendula extract, the staffs of Experimental Medicine and Surgery Center of FCM and the Mechanical Properties of Biological Laboratory of FEAGRI, and their sponsors: $\mathrm{PIBIC/Unicamp/CNPq}$.

\footnotetext{
${ }^{1}$ Kingsnorth A. The management of incisional hernia. Ann R Coll Surg Engl. 2006 May;88(3):252-60.

${ }^{2}$ Salameh JR, Talbott LM, May W, Gosheh B, Vig PJS, McDaniel DO. Role of biomarkers in incisional hernias. Am Surg. 2007 Jun;73(6):561-567; discussion 567-568.

${ }^{3}$ Parente LML, Lino Júnior R de S, Tresvenzol LMF, Vinaud MC, de Paula JR, Paulo NM. Wound Healing and Anti-Inflammatory Effect in Animal Models of Calendula officinalis L. Growing in Brazil. Evid Based Complement Alternat Med. 2012;2012:375671.
} 